\title{
Quality characteristics of Doenjang prepared with sweet potato
}

\author{
Su-Jin Cha, Sao-Ra Park, Dong-Han Kim* \\ Department of Food and Nutrition, Mokpo National University, Muan 58554, Korea
}

\section{고구마를 이용한 된장의 품질 특성}

\author{
차수진 · 박서라 · 김 동한* \\ 목포대학교 식품영양학과
}

\begin{abstract}
The effect of sweet potato on the quality of Doenjang was investigated during fermentation. Viable cells of yeast decreased gradually after 4 weeks of fermentation, but those of aerobic bacteria increased in the late stage. Amylase activity of Doenjang was higher in the late stage of fermentation, while neutral protease maintained high activity during fermentation. Hunter $L$ and b values of Doenjang decreased gradually during fermentation, while a value was increased. The pH of Doenjang decreased gradually until 10 weeks of fermentation, and the titratable acidity was low in the sweet potato added groups. The acid value was low in the Shinyulmi sweet potato added Doenjang. Water activity and oxidation-reduction potential of Doenjang decreased during fermentation. Reducing sugar of Doenjang decreased in the middle stage of fermentation, and it was low in sweet potato added groups. The alcohol content of Doenjang decreased after 2 weeks of fermentation. Amino and ammonia-type nitrogen of Doenjang increased during fermentation and reached the maximum after 10 and 12 weeks of fermentation, respectively. After 12 weeks fermentation, $8 \%$ of Shinyulmi sweet potato added Doenjang was more favorable taste, flavor and overall acceptability $(\mathrm{p}<0.05)$ than the control or the Yeonwhangmi sweet potato added groups.
\end{abstract}

Key words : Doenjang, sweet potato, physiochemical property

\section{서 론}

된장은 우리나라 고유의 전통발효식품으로 콩을 주원료 로 하여, 곡류 위주의 식생활에서 부족 되기 쉬운 단백질 함량이 높고 독특한 풍미를 가져 영양학적으로 우수한 조미 식품이다. 된장의 제조방법은 메주를 이용하여 간장을 제 조한 후 고형분을 이용하여 제조하는 전통식과 밀 등 곡류 에 국균인 Aspergillus oryzae를 접종한 koji를 이용하여 대두 를 발효·숙성시키는 개량식으로 구별되며 맛과 품질 특성 에서 큰 차이가 난다(1). 된장의 소비도 생활양식의 변화와 핵가족화, 편리성을 추구하는 소비자의 욕구변화로 전통식

*Corresponding author. E-mail : dhankim@mokpo.ac.kr Phone : 82-61-450-2524, Fax : 82-61-450-2529

Received 9 February 2017; Revised 16 March 2017; Accepted 16 March 2017.

Copyright (c) The Korean Society of Food Preservation. All rights reserved.
대신 공장에서 생산되는 개량식 된장의 수요가 점점 증가되 고 있다. 최근에는 웰빙을 추구하는 소비자의 요구에 맞추 어 된장 담금시 표고버섯(2)이나 녹차(3), 고추씨(4) 등 부재 료를 첨가하여 품질과 기능성을 향상시키려는 연구가 활발 히 진행되고 있다. 그러나 된장은 담금 재료의 종류(5)와 그 배합비율(6), koji 종류(7-9), 소금의 종류와 첨가농도 $(10,11)$ 등에 따라 발효 숙성 중에 성분조성과 맛 등 품질에 많은 차이가 있다. 전통식 된장은 Bacillus sp. 등 미생물이 발효 중에 향기와 성분변화에 관여되며 $(12,13)$, 개량식 된 장 제조에도 전통식 방법을 혼용하여 절충식으로 제조하거 나 국균 koji의 일부를 Rhizopus oryzae koji로 대체한 된장 (14)이 시도되었다. 또한 된장은 변색이 품질 저하의 주요 요인이 되기 때문에 숙성 중 갈변의 원인(15)과 갈변억제제 의 효과(16), 갈변억제제의 첨가시기(17) 등 저장 중 품질변 화에 관한 연구(18)가 보고된 바 있다.

한편 고구마는 메꽃과의 다년생 식물로 단위면적당 수확 량이 많을 뿐 아니라 최근에는 건강 대용식으로 소비가 
증가되고 있다(19). 고구마의 주요 기능성으로는 비타민 $\mathrm{A}$ 의 항암작용과 비타민 $\mathrm{E}$ 의 항산화작용, 식이섬유의 변비 해소, 칼륨과 칼슘의 혈압강하와 출혈방지, 안토시아닌 색 소의 기능성 등이 보고되어 있다(20).

따라서 고구마는 생식으로 이용되는 이외에도 웰빙을 표방하는 소비자들의 욕구증가로 민속주와 묵, 면류, 당면, 음료, 제과·제빵, 떡(21), 양갱, 요구르트, 된장(22) 등의 식품가공의 재료로 그 활용도가 점점 늘어나고 있다. 이에 본 연구에서는 고구마의 특성과 가공적성을 활용하기 위하 여 된장 담금시 소맥분 대신 일부를 밤고구마와 호박고구마 로 대체하여 된장을 제조하고, 고구마가 된장 발효 중의 미생물상 및 이화학적 품질특성에 미치는 영향을 비교 검토 하였다.

\section{재료 및 방법}

재 료

된장 제조에 사용한 고구마는 밤고구마로 신율미(SYM) 와 호박고구마로 연황미(YWM) 품종(무안황토고구마유통 센터)을, 대두는 백태, 밀가루는 우리밀을 농협 하나로마트 에서 구입하여 사용하였다. Koji는 토박이순창식품(주)에 서 밀가루로 제조한 Aspergillus oryzae koji와 대두로 만든 청국장 $k o j i$ 를 혼합하여 사용하였고, 식염은 천일염 $(\mathrm{NaCl}$ $80 \%$ 이상, Chungjungone, Seoul, Korea), 알코올은 무수 알 코올(순도 $99.8 \%$, Baker, Deventer, Netherlands)을 사용하였 다.

\section{된장의 제조}

된장 제조시 원료 처리로 고구마와 대두는 수세·침지한 후 물빼기를 하였고, 밀가루는 물을 $20 \%$ 혼합 첨가한 후 각각 $1.2 \mathrm{~kg} / \mathrm{cm}^{2}$ 압력으로 1 시간 증자하였다. 된장의 제조는 Table 1 과 같은 비율로 대조구의 소맥분 대신 고구마를 $4 \%, 8 \%$ 되게 혼합하여 소맥분 $k o j i$ 량을 조절하였으며, 식염 (9\%)과 알코올 $3 \%, \mathrm{w} / \mathrm{w})$ 을 혼합한 후 chopper로 마쇄하여 $5 \mathrm{~L}$ 의 플라스틱 용기에 담아 $20^{\circ} \mathrm{C}$ 에서 12 주간 발효시켰다.
생균수와 효소활성도

된장의 호기성세균수는 tryptic soy agar, 통성 혐기성세 균은 APT agar를 사용하여 평판도말한 후 $1.5 \%$ agar액을 중층하여 배양하였고, 효모는 rose bengal agar 배지를 사용 하여 평판도말법으로 $30^{\circ} \mathrm{C}$ 에서 1-3일간 배양한 후 계수하 였다(23). 효소액은 된장 $5 \mathrm{~g}$ 을 증류수로 희석하여 $100 \mathrm{~mL}$ 로 정용하고 실온에서 2시간 진탕추출한 후 동양여지 No. 2 로 여과하여 조효소액으로 하였다. 효소활성도는 $a$ -amylase의 경우 blue value 변법(24)에 준하여 측정한 후 반응 10 분 전후의 흡광도 차이에 희석배수를 곱하여 활성 도를 표시하였고, $\beta$-amylase는 Fuwa의 방법(24)에 준하여 된장 $1 \mathrm{~g}$ 에서 1 시간 반응 후 생성되는 환원당을 DNS법으로 정 량하여 $1 \mathrm{\mu M}$ 의 glucose 양을 1 unit로 하였다. 단백질 분해력은 Anson의 방법(25)에 준하여 $\mathrm{pH} 3.0,6.0$ (편의상 산성, 중성 protease로 함)으로 구별하여 측정한 후 활성도 는 된장 $1 \mathrm{~g}$ 에서 30 분에 생성하는 $1 \mu \mathrm{M}$ 의 tyrosine 양을 1 unit로 나타냈다.

\section{일반성분}

된장의 일반성분은 기준미증분석법(26)에 준하여 수분 은 $105^{\circ} \mathrm{C}$ 상압가열건조법, $\mathrm{pH}$ 는 $\mathrm{pH}$ meter(Onion $520 \mathrm{~A}+$, Beverly, MA, USA)로 직접 측정하였고, 적정산도는 0.1 $\mathrm{N} \mathrm{NaOH}$ 를 이용하여 $\mathrm{pH} 8.3$ 까지 적정법으로, 환원당은 DNS법, 알코올은 산화법, 아미노산성 질소는 Formol적정 법, 암모니아성 질소 함량은 Folin법으로 정량하였다. 산가 는 된장 $2.5 \mathrm{~g}$ 을 삼각 flask에 취하고 ether-ethanol 혼합액 (1:2) $100 \mathrm{~mL}$ 를 넣어 자석교반기로 10 분간 용출시킨 후 phenolphthalein을 지시약으로 $0.1 \mathrm{~N}$ ethanol성 $\mathrm{KOH}$ 용액으 로 적정하여 그 소비량으로 계산하였고(8), 산화환원전위 (Oxidation-reduction potential, ORP)는 된장을 2 배 희석한 후 ORP meter(Onion 525A + , Beverly, MA, USA)를 이용하 여 직접 측정하였다. 수분활성도는 Novasina LabSwift-Aw (CH-8853, Novasina AG, Lachen, Switzerland)로, 색도는 색차계(Chromameter CR-200, Minolta, Osaka, Japan)로 측 정하여 Hunter scale에 의해 L(lightness), a(redness), $\mathrm{b}($ yellowness) 값으로 표시하였다.

Table 1. Mixing ratio of raw materials for preparation of Doenjang

\begin{tabular}{ccccccccc} 
(unit: g) \\
\hline & Sweet potato & Soybean koji & Wheat koji & Soybean & Wheat flour & Salt & Water & Ethanol \\
\hline Control & 0 & 600 & 600 & 1150 & 200 & 450 & 1850 & 150 \\
SYM $^{11} 4$ & 200 & 600 & 600 & 1150 & 0 & 450 & 1850 & 150 \\
SYM8 $^{2}$ & 400 & 600 & 400 & 1150 & 0 & 450 & 1850 & 150 \\
YWM $^{2} 4$ & 200 & 600 & 600 & 1150 & 0 & 450 & 1850 & 150 \\
YWM8 $^{2}$ & 400 & 600 & 400 & 1150 & 0 & 450 & 1850 & 150 \\
\hline
\end{tabular}

${ }^{1)}$ SYM, Shinyulmi sweet potato added Doenjang.

${ }^{2)}$ YWM, Yeonwhangmi sweet potato added Doenjang. 
관능검사

12 주간 발효시킨 된장을 20 명의 식품영양학과 학생들을 대상으로 맛과 향기, 색, 종합적인 기호도를 최고 7점 최저 1 점의 7단계의 채점법으로 평가하여 얻은 점수를 SPSS/PC package 23.0(SPSS Inc., Chicago, IL, USA)을 이용하여 분산 분석을 하고 Duncan's multiple range test에 의해 $\mathrm{p}<0.05$ 수준에서 통계처리 하였다.

\section{결과 및 고찰}

미생물상

된장은 발효과정에서 미생물의 증식에 의한 원료성분의 분해와 대사산물에 의하여 맛과 향기성분 등 품질에 중요한 영향을 준다. 된장 발효 중 미생물상의 변화는 Table 2 와 같이 유의적인 차이는 없으나 효모수는 발효 4 주까지 근소 하게 증가하였으나 8주 이후에는 감소하여 12주에 2.63-3.33 $\log \mathrm{CFU} / \mathrm{g}$ 수준이었고, 호기성 세균은 담금 시 청국장 $k o j i$ 를 혼합한 관계로 8.75-8.91 log CFU/g으로 국균 koji만을 사용한 된장(4)의 $10^{7}-10^{8} \mathrm{CFU} / \mathrm{g}$ 보다 많았으나 발효 중에 조금 감소하다가 12 주에 증가하는 경향이었다. 혐기성 세 균은 호기성 세균과는 달리 8 주경에 증가하였다가 그 이후 에 감소하는 경향을 보였으며, 세균수는 발효 8 주를 제외하 고는 호기성 세균수에 비하여 $1 \log \mathrm{CFU} / \mathrm{g}$ 정도 적었다. 시험구간에는 특징적인 차이는 없었고 발효중 미생물수의 변화도 적었다. 이러한 결과는 저식염 된장에서 효모수가 대조구는 발효 6-8주에 $10^{6} \mathrm{CFU} / \mathrm{g}$ 이었으나 알코올이나 겨자, 마늘 등 항균물질을 첨가한 경우 $10^{3} \mathrm{CFU} / \mathrm{g}$ 으로 저하
되었고 국균만을 이용한 개량식이 메주를 이용한 전통식 된장에 비하여 세균수가 적었던 보고(10)와 유사한 경향이 었다. 따라서 된장 담금 시 알코올을 $3 \%$ 첨가하면 발효 중 이상발효의 원인이 되는 효모의 증식이 효과적으로 조절 되는 것으로 판단되었다. 그러나 본 실험 된장의 발효 기간 중 효모수는 30일에 3.78-3.98 $\log \mathrm{CFU} / \mathrm{g}$ 이었던 전통식 된 장(2)에 비하여 많았으나, 공장식의 경우 30 일 발효 후 효모 수가 $3.9 \times 10^{6} \mathrm{CFU} / \mathrm{g}$ 이었던 보고(18)에 비하여 효모수는 적 어 차이가 있었다.

\section{효소활성도}

발효 중 원료성분을 분해하여 단맛과 구수한 맛 생성에 중요한 효소활성의 변화는 Table 3 과 같이 $a$-amylase와 $\beta$ -amylase 모두 발효 4주까지 높은 활성을 유지하였으나 8 주 경에 급격히 감소하여 낮은 활성을 보이다가 12 주에는 증 가하는 경향이었다. Protease는 Table 4와 같이 산성 protease 활성은 담금 직후에 제일 높았고 4주에 급격히 저하하여 8 주까지 낮은 활성을 보였으나 그 이후에 다시 증가하는 경향이었다 $(\mathrm{p}<0.05)$. 그러나 중성 protease 활성은 산성 protease와는 달리 담금 직후에는 낮았으나 4주에 급격히 증가한 후 서서히 감소하는 경향으로 발효 전 기간 동안 비교적 높은 활성을 유지하여, 단백질 분해는 Fig. 1에서 보는바와 발효 중 $\mathrm{pH}$ 가 6 전후이기 때문에 주로 중성 protease에 의하여 숙성이 진행되는 것으로 판단되었다. 이 러한 결과는 전통식 된장이 발효 30 일까지 amylase와 protease 활성이 증가하다가 발효가 진행되면서 감소되었 고(2) 및 Aspergillus oryzae koji를 이용한 개량식 된장에서 $\beta$-amylase와 중성 protease는 각각 담금 10 일과 30 일에 높은

Table 2. Changes in viable cell counts of microorganism of Doenjang during fermentation at $20^{\circ} \mathrm{C}$

(unit: $\log \mathrm{CFU} / \mathrm{g}$ )

\begin{tabular}{ccccccc}
\hline & $\begin{array}{c}\text { Fermentation period } \\
\text { (week) }\end{array}$ & Control & SYM4 & SYM8 & YWM4 & YWM8 \\
\cline { 2 - 7 } Yeast & 0 & $4.71 \pm 0.36^{2)}$ & $4.92 \pm 0.61$ & $4.98 \pm 0.50$ & $4.39 \pm 0.28$ & $4.53 \pm 0.51$ \\
& 4 & $4.90 \pm 0.55$ & $4.97 \pm 0.41$ & $5.11 \pm 0.30$ & $5.25 \pm 0.24$ & $4.90 \pm 0.59$ \\
& 8 & $4.25 \pm 0.43$ & $4.12 \pm 0.50$ & $4.28 \pm 0.20$ & $4.24 \pm 0.42$ & $4.51 \pm 0.40$ \\
\hline \multirow{5}{*}{ Aerobic bacteria } & 12 & $2.63 \pm 0.12$ & $2.98 \pm 0.50$ & $2.69 \pm 0.52$ & $3.08 \pm 0.30$ & $3.33 \pm 0.44$ \\
& 0 & $8.75 \pm 0.50$ & $8.82 \pm 0.31$ & $8.91 \pm 0.46$ & $8.91 \pm 0.41$ & $8.86 \pm 0.51$ \\
& 4 & $7.75 \pm 0.39$ & $7.67 \pm 0.36$ & $7.78 \pm 0.21$ & $7.61 \pm 0.50$ & $7.73 \pm 0.52$ \\
\hline \multirow{5}{*}{ Anaerobic bacteria } & 8 & $7.25 \pm 0.24$ & $7.95 \pm 0.64$ & $7.49 \pm 0.44$ & $7.53 \pm 0.60$ & $7.10 \pm 0.40$ \\
& 12 & $8.46 \pm 0.45$ & $8.13 \pm 0.62$ & $8.59 \pm 0.50$ & $8.25 \pm 0.25$ & $7.91 \pm 0.58$ \\
\hline & 0 & $7.76 \pm 0.63$ & $7.51 \pm 0.74$ & $7.81 \pm 0.31$ & $7.71 \pm 0.30$ & $7.77 \pm 0.55$ \\
& 4 & $6.84 \pm 0.42$ & $6.58 \pm 0.50$ & $6.63 \pm 0.37$ & $6.51 \pm 0.40$ & $6.71 \pm 0.20$ \\
& 12 & $7.22 \pm 0.41$ & $7.28 \pm 0.38$ & $7.11 \pm 0.23$ & $6.85 \pm 0.50$ & $7.15 \pm 0.47$ \\
\hline
\end{tabular}

${ }^{1)}$ SYM, Shinyulmi sweet potato added Doenjang, YWM, Yeonwhangmi sweet potato added Doenjang.

${ }^{2)}$ Values are mean $\pm \mathrm{SD}(\mathrm{n}=3)$. 
활성을 보였던 보고(6)와 유사한 경향이었다. 또한 amylase 와 protease 모두 고구마 종류에 따라 유의적인 차이는 없었 으나(p<0.05) 고구마 $8 \%$ 첨가구가 $4 \%$ 구에 비하여 담금 시 국균 koji 첨가 비율이 낮았던 관계로 발효 초기에는 효소활 성이 낮았으나 후기에는 미생물의 증식에 의해 생성되는 효소의 영향 때문에 큰 차이가 없어 $\mathrm{Bae}$ 등(22)의 보고와 유사하였다. 한편 효소활성을 Table 2의 생균수와 비교하면 amylase와 산성 protease 활성은 호기성 세균수가 높았던 담금 직후와 발효 12 주에 효소 활성도가 높아 생균수와 효소활성도는 유사한 경향이었으나, 중성 protease와는 차 이가 있었다. 이것으로 미루어보아 된장 발효 중 효소활성 은 생균수보다는 세균의 종류에 따라 차이가 있는 것으로 판단되었다.
색 도

된장 품질요소로 중요한 색의 변화를 색도계로 측정한 결과는 Table 5 와 같이 발효가 진행되면서 밝기인 L 값은 저하되었고 적색도인 a 값은 증가하였으며 이러한 변화는 발효 4주 이내에서 크게 변하였다. 황색도인 $\mathrm{b}$ 값은 이와는 달리 발효 4주까지는 큰 차이가 없었으나 그 이후에 저하하 는 경향이었다. 시험구간에는 밤고구마(SYM)를 혼합한 된 장이 호박고구마(YWM)를 혼합한 구에 비하여 발효 후기 에 $\mathrm{L}$ 과 $\mathrm{b}$ 값이 높아 밝은 색을 띄는 경향이었다 $(\mathrm{p}<0.05)$. 이러한 결과는 보리된장 제조시 두유박의 혼합비율이 증가 하면 $\mathrm{L}$ 과 $\mathrm{b}$ 값이 증가하고 $\mathrm{a}$ 값이 저하되었던 보고(5)와는 차이가 있었다. 그러나 30 일간 숙성시킨 개량식 된장에서 $\mathrm{L}$ 과 $\mathrm{a}, \mathrm{b}$ 값이 각각 44.5-45.2, 6.2-7,2, 15.4-15.6이었고(18),

Table 3. Changes in amylase activity of Doenjang during fermentation at $20^{\circ} \mathrm{C}$

(unit/g)

\begin{tabular}{|c|c|c|c|c|c|c|}
\hline & \multirow{2}{*}{$\begin{array}{l}\text { Fermentation period } \\
\text { (week) }\end{array}$} & \multicolumn{5}{|c|}{ Doenjang $^{1)}$} \\
\hline & & Control & SYM4 & SYM8 & YWM4 & YWM8 \\
\hline \multirow{4}{*}{ a-Amylase } & 0 & $11.17 \pm 1.58^{2)}$ & $11.13 \pm 1.35$ & $10.47 \pm 1.55$ & $11.84 \pm 1.50$ & $10.43 \pm 1.76$ \\
\hline & 4 & $21.67 \pm 2.00$ & $21.63 \pm 0.63$ & $20.10 \pm 0.20$ & $26.50 \pm 3.75$ & $22.66 \pm 2.30$ \\
\hline & 8 & $4.80 \pm 1.70$ & $6.70 \pm 4.10$ & $4.84 \pm 1.65$ & $5.20 \pm 3.10$ & $7.70 \pm 2.26$ \\
\hline & 12 & $26.37 \pm 2.61$ & $22.02 \pm 3.00$ & $22.33 \pm 1.55$ & $24.87 \pm 2.05$ & $27.56 \pm 1.40$ \\
\hline \multirow{4}{*}{$\beta$-Amylase } & 0 & $1,752.6 \pm 75.9$ & $1,738.7 \pm 72.7$ & $1,663.1 \pm 91.8$ & $1,692.4 \pm 72.3$ & $1,674.0 \pm 91.4$ \\
\hline & 4 & $1,792.7 \pm 50.2^{\mathrm{b} 3)}$ & $1,922.5 \pm 13.0^{\mathrm{a}}$ & $1,911.6 \pm 8.1^{\mathrm{a}}$ & $1,894.9 \pm 57.3^{\mathrm{a}}$ & $1,841.3 \pm 16.0^{b}$ \\
\hline & 8 & $313.2 \pm 58.0^{\mathrm{b}}$ & $353.7 \pm 85.4^{b}$ & $333.7 \pm 9.6^{b}$ & $459.0 \pm 10.0^{\mathrm{a}}$ & $373.9 \pm 21.3^{\mathrm{ab}}$ \\
\hline & 12 & $1,301.4 \pm 98.3$ & $1,447.2 \pm 87.7$ & $1,468.7 \pm 80.3$ & $1,614.3 \pm 10.5$ & $1,517.6 \pm 12.5$ \\
\hline
\end{tabular}

${ }^{1)}$ SYM, Shinyulmi sweet potato added Doenjang, YWM, Yeonwhangmi sweet potato added Doenjang.

${ }^{2)}$ Values are mean $\pm \mathrm{SD}(\mathrm{n}=3)$.

${ }^{3)}$ Means with same letter in row are not significantly different by Duncan's multiple range test $(p<0.05)$.

Table 4. Changes in protease activities of Doenjang during fermentation at $20^{\circ} \mathrm{C}$

\begin{tabular}{|c|c|c|c|c|c|c|}
\hline & \multirow{2}{*}{$\begin{array}{l}\text { Fermentation period } \\
\text { (week) }\end{array}$} & \multicolumn{5}{|c|}{ Doenjang $^{1)}$} \\
\hline & & Control & SYM4 & SYM8 & YWM4 & YWM8 \\
\hline \multirow{4}{*}{ Acidic protease } & 0 & $8.06 \pm 0.45^{2) b c 3)}$ & $9.21 \pm 0.22^{\mathrm{a}}$ & $8.57 \pm 0.28^{\mathrm{ab}}$ & $7.31 \pm 0.29^{\text {cd }}$ & $6.90 \pm 0.70^{\mathrm{d}}$ \\
\hline & 4 & $1.13 \pm 0.13^{\mathrm{c}}$ & $2.89 \pm 0.52^{\mathrm{a}}$ & $2.52 \pm 0.99^{\mathrm{ab}}$ & $1.63 \pm 0.03^{b c}$ & $1.76 \pm 0.13^{b c}$ \\
\hline & 8 & $0.55 \pm 0.15$ & $0.43 \pm 0.29$ & $0.76 \pm 0.15$ & $0.59 \pm 0.06$ & $0.43 \pm 0.18$ \\
\hline & 12 & $2.39 \pm 0.16^{\mathrm{bc}}$ & $4.16 \pm 0.73^{\mathrm{ab}}$ & $2.02 \pm 0.51^{c}$ & $3.53 \pm 1.26^{\mathrm{ab}}$ & $4.74 \pm 0.53^{\mathrm{a}}$ \\
\hline \multirow{4}{*}{ Neutral protease } & 0 & $1.76 \pm 0.13$ & $1.88 \pm 0.14$ & $1.63 \pm 0.09$ & $1.97 \pm 0.22$ & $1.51 \pm 0.28$ \\
\hline & 4 & $8.45 \pm 1.51$ & $8.70 \pm 1.92$ & $9.59 \pm 2.28$ & $9.41 \pm 2.10$ & $6.28 \pm 0.83$ \\
\hline & 8 & $5.13 \pm 1.44$ & $6.38 \pm 1.10$ & $6.77 \pm 0.94$ & $7.00 \pm 0.62$ & $7.38 \pm 0.62$ \\
\hline & 12 & $5.39 \pm 1.25^{\mathrm{a}}$ & $2.93 \pm 0.12^{\mathrm{c}}$ & $3.37 \pm 0.39^{b c}$ & $4.80 \pm 0.87^{\mathrm{ab}}$ & $4.53 \pm 0.40^{\mathrm{ab}}$ \\
\hline
\end{tabular}

${ }^{1)}$ SYM, Shinyulmi sweet potato added Doenjang, YWM, Yeonwhangmi sweet potato added Doenjang.

${ }^{2)}$ Values are mean $\pm \mathrm{SD}(\mathrm{n}=3)$.

${ }^{3)}$ Means with same letter in row are not significantly different by Duncan's multiple range test $(p<0.05)$. 
숙성 중에 갈변으로 $\mathrm{L}$ 값이 감소되었던 보고(17)와 유사한 경향이었다. 한편 된장은 Maillard 반응에 의한 갈변으로 명도가 저하되고 색이 진해져 상품성이 떨어지나 발효 중에 생성되는 oxalic acid 등 유기산이 발효 초기의 $\mathrm{pH}$ 를 낮추어 갈변을 억제(17)하는 것으로 보고된 바 있다.

\section{$\mathrm{pH}$ 와 적정산도}

된장 발효 중 미생물의 대사산물과 밀접한 관련이 있는 $\mathrm{pH}$ 와 적정산도의 변화는 $\mathrm{Fig}$. 1 과 같이 $\mathrm{pH}$ 는 발효가 진행되 면서 서서히 저하하여 10 주에 $\mathrm{pH}$ 5.85-5.92에 달하였으나 12 주에는 조금 상승하였다. 한편 주 등(7)은 15 일 숙성시킨 된장의 $\mathrm{pH}$ 는 5.91-6.46으로 메주 종류에 따라 된장의 $\mathrm{pH}$ 는
차이가 있었고 개량식 메주에 납두를 혼합할수록 $\mathrm{pH}$ 는 높 았다고 보고하였다. 적정산도는 발효가 진행되면서 당류가 분해되어 유기산으로 변환되고 glutamic acid, aspartic acid 등 유리 아미노산이 생성되기 때문에(11) 발효 중에 점진적 으로 증가되었으나 8 주 이후에는 감소하였다. 시험구간에 는 근소하지만 고구마 첨가 된장이 발효 후기에 산도가 낮았는데 이는 고구마가 소맥분보다 단백질이 적어 발효 분해산물에 의한 완충능이 적기 때문인 것으로 판단되었 다. 또한 적정산도는 총세균수보다는 젖산균의 증식과 효 모에 의해 생성된 알코올이 초산으로 산화되어 증가되는 것으로 보고(10)된 바 있다.

Table 5. Changes in Hunter's color value of Doenjang during fermentation at $20^{\circ} \mathrm{C}$

\begin{tabular}{|c|c|c|c|c|c|c|}
\hline \multirow{2}{*}{ Color value } & \multirow{2}{*}{$\begin{array}{l}\text { Fermentation period } \\
\text { (week) }\end{array}$} & \multicolumn{5}{|c|}{ Doenjang ${ }^{1)}$} \\
\hline & & Control & SYM4 & SYM8 & YWM4 & YWM8 \\
\hline \multirow{4}{*}{$\mathrm{L}$} & 0 & $50.88 \pm 1.83^{2)}$ & $57.72 \pm 3.16$ & $51.24 \pm 1.32$ & $52.40 \pm 3.17$ & $52.51 \pm 3.90$ \\
\hline & 4 & $43.52 \pm 1.57$ & $44.27 \pm 2.67$ & $44.53 \pm 2.74$ & $42.09 \pm 0.66$ & $42.82 \pm 1.98$ \\
\hline & 8 & $39.49 \pm 2.35$ & $40.86 \pm 1.46$ & $40.65 \pm 1.49$ & $39.56 \pm 2.12$ & $39.56 \pm 2.16$ \\
\hline & 12 & $36.22 \pm 0.16^{3) b}$ & $37.90 \pm 0.44^{\mathrm{ab}}$ & $39.16 \pm 0.61^{a}$ & $36.28 \pm 1.42^{\mathrm{b}}$ & $36.28 \pm 0.91^{b}$ \\
\hline \multirow{4}{*}{$\mathrm{a}$} & 0 & $2.42 \pm 0.31$ & $2.73 \pm 0.27$ & $2.87 \pm 0.42$ & $3.15 \pm 0.30$ & $3.25 \pm 0.26$ \\
\hline & 4 & $5.32 \pm 0.42$ & $5.07 \pm 0.68$ & $4.76 \pm 0.41$ & $5.12 \pm 0.61$ & $5.28 \pm 0.27$ \\
\hline & 8 & $5.86 \pm 0.64$ & $5.91 \pm 0.69$ & $5.83 \pm 0.68$ & $6.11 \pm 0.26$ & $6.10 \pm 0.53$ \\
\hline & 12 & $6.98 \pm 0.69$ & $6.40 \pm 0.58$ & $6.73 \pm 0.21$ & $7.07 \pm 0.75$ & $6.62 \pm 0.32$ \\
\hline \multirow{4}{*}{$\mathrm{b}$} & 0 & $21.54 \pm 0.52^{c}$ & $22.36 \pm 0.64^{b c}$ & $22.05 \pm 0.54^{c}$ & $23.71 \pm 0.48^{\mathrm{a}}$ & $23.21 \pm 0.71^{\mathrm{ab}}$ \\
\hline & 4 & $21.46 \pm 0.22$ & $21.71 \pm 0.61$ & $21.83 \pm 0.64$ & $21.04 \pm 0.33$ & $22.04 \pm 0.75$ \\
\hline & 8 & $18.09 \pm 0.30^{c}$ & $18.20 \pm 0.11^{\mathrm{c}}$ & $18.67 \pm 0.22^{b c}$ & $19.39 \pm 0.66^{\mathrm{ab}}$ & $19.37 \pm 0.25^{\mathrm{a}}$ \\
\hline & 12 & $16.54 \pm 0.61^{b}$ & $17.46 \pm 1.20^{\mathrm{ab}}$ & $18.76 \pm 0.32^{\mathrm{a}}$ & $16.68 \pm 0.30^{b}$ & $16.65 \pm 0.71^{b}$ \\
\hline
\end{tabular}

${ }^{1)}$ SYM, Shinyulmi sweet potato added Doenjang, YWM, Yeonwhangmi sweet potato added Doenjang.

${ }^{2)}$ Values are mean $\pm \mathrm{SD}(\mathrm{n}=3)$.

${ }^{3)}$ Means with same letter in row are not significantly different by Duncan's multiple range test $(\mathrm{p}<0.05)$.

Table 6. Changes in moisture content and acid value of Doenjang during fermentation at $20^{\circ} \mathrm{C}$

\begin{tabular}{|c|c|c|c|c|c|c|}
\hline & \multirow{2}{*}{$\begin{array}{l}\text { Fermentation period } \\
\text { (week) }\end{array}$} & \multicolumn{5}{|c|}{ Doenjang } \\
\hline & & Control & SYM4 & SYM8 & YWM4 & YWM8 \\
\hline \multirow{4}{*}{$\begin{array}{l}\text { Moisture } \\
(\%)\end{array}$} & 0 & $51.22 \pm 0.04^{2(2) 3)}$ & $52.68 \pm 0.08^{b}$ & $54.07 \pm 0.11^{\mathrm{a}}$ & $52.82 \pm 0.03^{\mathrm{b}}$ & $53.14 \pm 0.59^{b}$ \\
\hline & 4 & $52.93 \pm 0.06^{\mathrm{e}}$ & $54.62 \pm 0.03^{\mathrm{d}}$ & $56.29 \pm 0.14^{\mathrm{b}}$ & $54.83 \pm 0.12^{\mathrm{c}}$ & $56.48 \pm 0.12^{\mathrm{a}}$ \\
\hline & 8 & $53.10 \pm 0.09^{c}$ & $55.24 \pm 0.14^{\mathrm{b}}$ & $56.23 \pm 0.13^{\mathrm{a}}$ & $55.19 \pm 0.15^{b}$ & $56.46 \pm 0.23^{\mathrm{a}}$ \\
\hline & 12 & $52.64 \pm 0.13^{\mathrm{e}}$ & $53.95 \pm 0.05^{\mathrm{d}}$ & $55.54 \pm 0.16^{b}$ & $54.30 \pm 0.25^{\mathrm{c}}$ & $55.99 \pm 0.11^{\mathrm{a}}$ \\
\hline \multirow{4}{*}{$\begin{array}{l}\text { Acid value } \\
(\mathrm{mg} / \mathrm{g})\end{array}$} & 0 & $14.34 \pm 0.80^{\mathrm{b}}$ & $13.66 \pm 0.51^{b}$ & $14.56 \pm 0.50^{\mathrm{ab}}$ & $15.46 \pm 0.23^{\mathrm{a}}$ & $14.11 \pm 0.60^{b}$ \\
\hline & 4 & $19.04 \pm 0.43^{\mathrm{b}}$ & $20.38 \pm 0.14^{\mathrm{a}}$ & $19.26 \pm 0.06^{b}$ & $18.37 \pm 0.26^{\mathrm{c}}$ & $19.49 \pm 0.50^{b}$ \\
\hline & 8 & $21.50 \pm 0.42^{\mathrm{a}}$ & $21.53 \pm 0.42^{\mathrm{a}}$ & $20.16 \pm 0.60^{\mathrm{b}}$ & $20.83 \pm 0.48^{\mathrm{ab}}$ & $21.28 \pm 0.41^{\mathrm{a}}$ \\
\hline & 12 & $20.61 \pm 0.29^{c}$ & $22.85 \pm 0.32^{\mathrm{a}}$ & $21.73 \pm 0.30^{b}$ & $21.28 \pm 0.27^{\mathrm{b}}$ & $19.94 \pm 0.43^{\mathrm{d}}$ \\
\hline
\end{tabular}

\footnotetext{
${ }^{1)}$ SYM, Shinyulmi sweet potato added Doenjang, YWM, Yeonwhangmi sweet potato added Doenjang.

${ }^{2)}$ Values are mean $\pm \mathrm{SD}(\mathrm{n}=3)$.

${ }^{3)}$ Means with same letter in row are not significantly different by Duncan's multiple range test $(\mathrm{p}<0.05)$.
} 

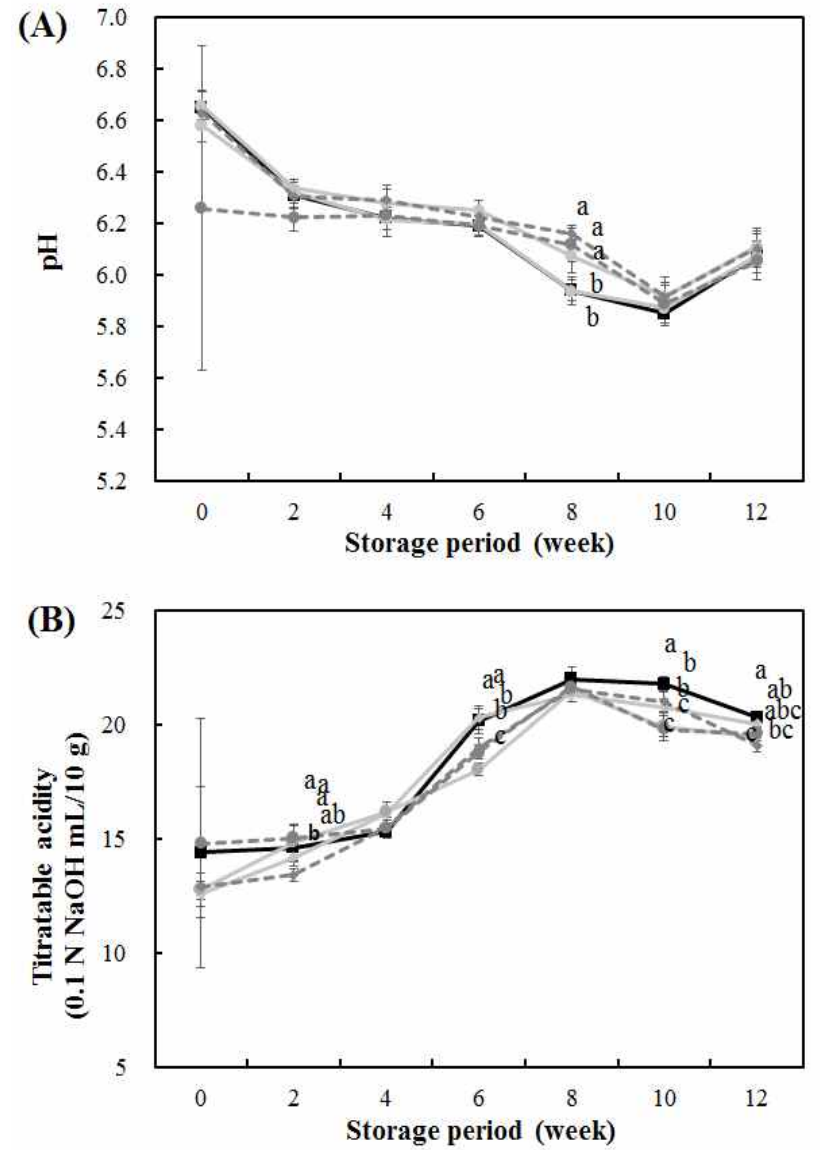

Fig. 1. Changes in $\mathrm{pH}$ and titratable acidity of Doenjang during fermentation at $20^{\circ} \mathrm{C}$.

$\rightarrow$ Control - SYM4 $\rightarrow$ SYM8 $-\rightarrow-$ YWM4 - - YWM8

SYM, Shinyulmi sweet potato added Doenjang, YWM, Yeonwhangmi sweet potato added Doenjang.

\section{수분과 산가}

된장의 발효 중 수분함량 변화는 Table 6과 같이 발효가 진행되면서 8주까지는 근소하게 증가하였으나 그 이후에 는 감소하였다. 발효 중에 수분의 증가는 원료성분이 가수 분해 되어 수용성 물질이 증가되었기 때문이다(3). 시험구 간에는 고구마의 수분함량이 밀가루보다 많았기 때문에 고구마 $8 \%$ 첨가구가 $4 \%$ 첨가구보다 된장의 수분함량이 유의적으로 많았다(p<0.05). 된장의 발효중 지방의 분해와 밀접한 산가는 발효가 진행되면서 증가되어 8주경에 최고 에 달했고, 호박고구마에 비하여 밤고구마를 혼합한 된장 에서 조금 높았다. Joo 등은(7) 된장의 산가는 발효기간 중 $10-20 \mathrm{mg} / \mathrm{g}$ 수준으로 발효가 빠를수록 산가의 변화는 심하였으며 재래식 메주된장보다 개량식으로 제조한 된장 이 산가가 낮아 좋지 않은 냄새가 적었다고 보고 한 바 있다.

\section{산화환원전위와 수분활성도}

된장의 발효 중 산화환원전위(ORP)와 수분활성도의 변
화는 Fig. 2와 같이 ORP는 발효가 진행되면서 12주까지 저하되었고, 저하정도는 발효 2주인 초기와 후기인 12 주에 심하였으나 시험구간의 차이는 없었다. 발효 중에 ORP가 $-200 \mathrm{mV}$ 이하로 저하되면 호기성 세균의 증식이 억제되어 혐기성균의 증식조건이 유리하게 되나(28), 본 실험 된장의 경우 ORP가 발효 전 기간 동안 호기성 세균의 생육을 억제 하는 수준으로 저하되지는 않았다. 그러나 밀가루 $k o j i$ 만을 사용한 저식염 된장의 경우 발효중에 ORP가 -200 mV 이하 였던 보고(10)와는 차이가 있었는데 이는 담금시 청국장 $k o j i$ 를 국균 $k o j i$ 와 $1: 1$ 의 비율로 혼합하였기 때문이었던 것으로 판단되었다. 수분활성도는 발효 8 주까지 감소하였 다. 이를 Table 6의 수분량과 비교하여 보면 발효가 진행되 면서 수분량이 증가하였음에도 불구하고 수분활성도가 저 하되었는데 이는 발효 중에 원료성분이 분해되어 저분자화 됨에 따라 수분량의 증가에 비하여 용질의 몰분율 증가비율 이 높았기(27) 때문인 것으로 판단되었다.
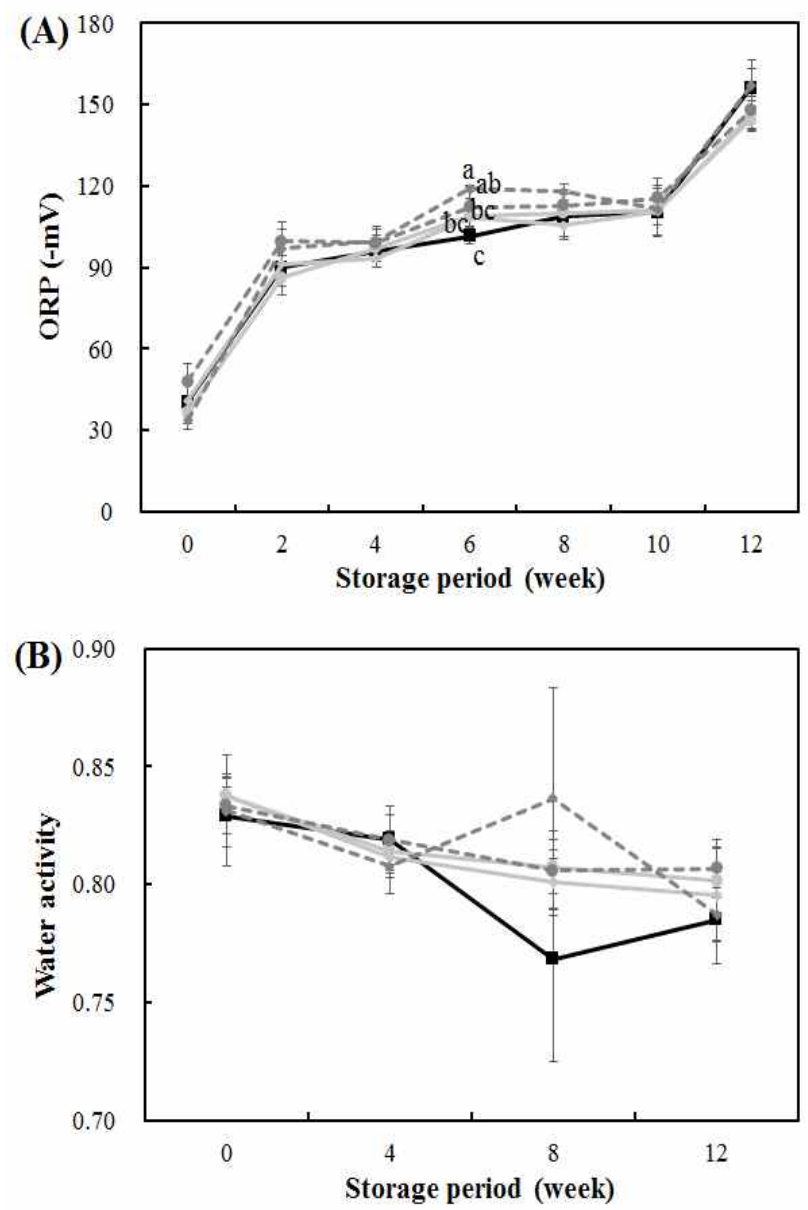

Fig. 2. Changes in oxidation-reduction potential and water activity of Doenjang during fermentation at $20^{\circ} \mathrm{C}$.

$\rightarrow$ - Control —SYM4 —SYM8 - - - YWM4 - - - YWM8 SYM, Shinyulmi sweet potato added Doenjang, YWM, Yeonwhangmi sweet potato added Doenjang. 


\section{환원당과 알코올}

된장 발효 중 전분질의 분해로 생성되는 환원당의 변화 는 Fig. 3과 같다. 소맥분을 전분질원으로 사용한 대조구는 6주까지 환원당이 증가하여 $9.24 \%$ 로 최고에 달하였고 그 이후에 감소하였다. 고구마를 이용한 경우 밤고구마는 2주, 호박고구마는 4주까지 환원당이 증가하였으나 그 이후에 는 감소하여 12 주 발효 후에는 밤고구마 $8 \%$ 첨가 된장은 $6.27 \%$, 호박고구마 $8 \%$ 첨가구는 $6.60 \%$ 로 대조구의 $7.91 \%$ 에 비하여 낮았다. 전분질의 분해로 생성되는 환원당이 발 효 중에 감소하는 것은 생성된 환원당이 미생물 증식 또는 유기산, 알코올 발효의 기질로 이용되기 때문이다. 한편 소맥분을 이용한 개량식 된장(6)의 경우 $k o j i$ 배합비율에 따라 환원당은 10-30일 사이에 7.71-9.96\%로 최고에 달했 고, 주 등 $(8)$ 은 $\mathrm{koji}$ 의 종류에 따라 된장의 환원당 함량은 차이가 있어 발효 20일에 7.17-13.11\%로 최고에 달했다고 보고하여 $k o j i$ 의 종류와 배합비율에 따라 차이(10)가 있었 다. 알코올 함량은 배합과정에서 휘발되어 담금 직후에 2.70-2.84\%이었으며 발효 2주에 조금 증가하였으나 그 이
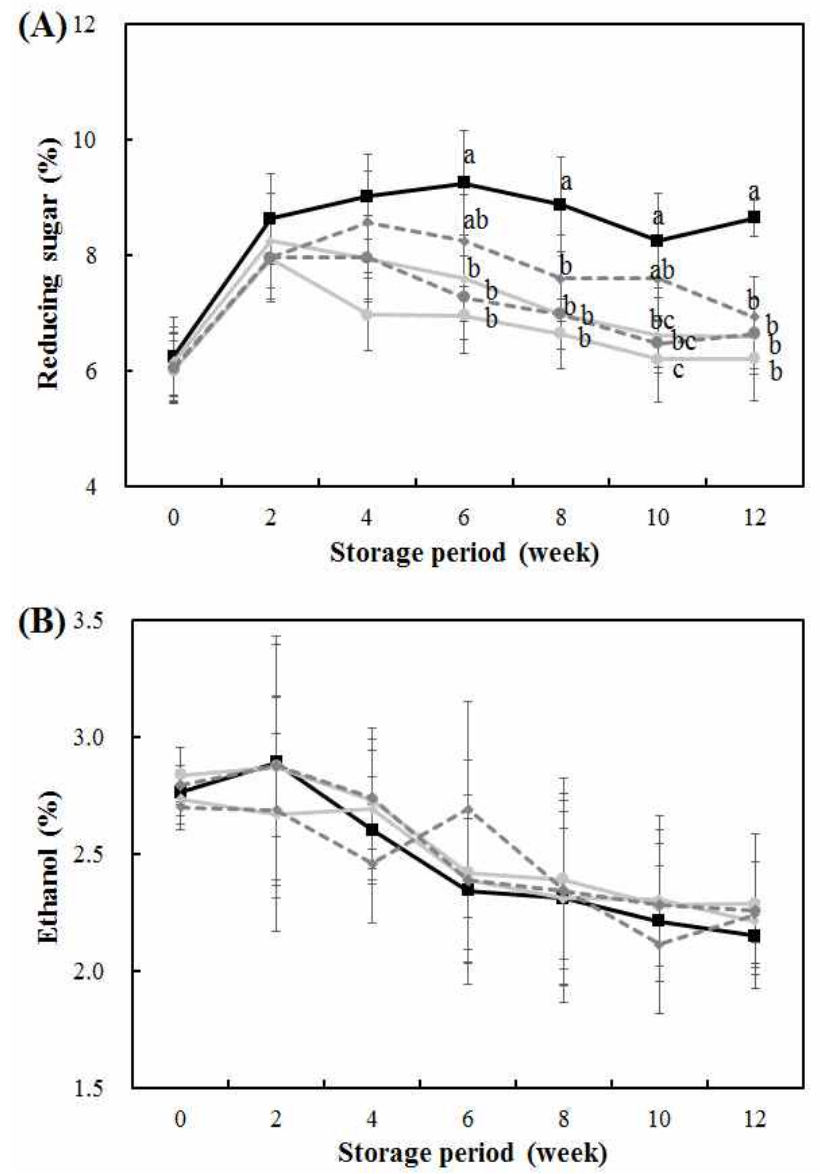

Fig. 3. Changes in reducing sugar and ethanol contents of Doenjang during fermentation at $20^{\circ} \mathrm{C}$.

$\rightarrow$-Control $\longrightarrow$ SYM4 $\longrightarrow$ SYM8 - - YWM4 - - - YWM8 SYM, Shinyulmi sweet potato added Doenjang, YWM, Yeonwhangmi sweet potato added Doenjang.
후에는 서서히 감소하여 12 주 발효 후에는 2.15-2.28\%로 저하되었다. 이러한 경향은 $\mathrm{koji}$ 의 종류를 달리한 된장에서 알코올은 발효 중에 증가하여 40일에 0.26-3.42\%로 실험구 에 따라 현저한 차이를 보였던 보고(8)와는 차이가 있었는 데, 이는 된장 담금시 $3 \%$ 알코올을 혼합한 관계로 효모의 생육이 부분적으로 억제되어 상대적으로 알코올 생성이 적었던 것으로 판단되었다.

\section{질소성분}

된장 발효 과정중 구수한 맛 성분과 밀접한 관계가 있는 아미노산성 질소의 변화는 Fig. 4와 같이 담금 직후 0.06-0.07\%이었던 것이 발효가 진행되면서 증가되어 10 주 에는 0.29-0.33\%로 증가하였고 그 이후에는 감소하였다. 이러한 결과는 제국원료를 달리한 개량식 된장의 아미노산 성 질소가 발효 중에 증가하여 60일과 90일에 각각 262-320 $\mathrm{mg} \%$ (22)와 304-487 mg\%(6) 범위이었던 보고와 유사한 경 향이었다. 또한 Park 등(12)은 된장의 아미노산성 질소는 $k o j i$ 의 사용균주에 따라 다르며 $k o j i$ 된장이 재래식이나
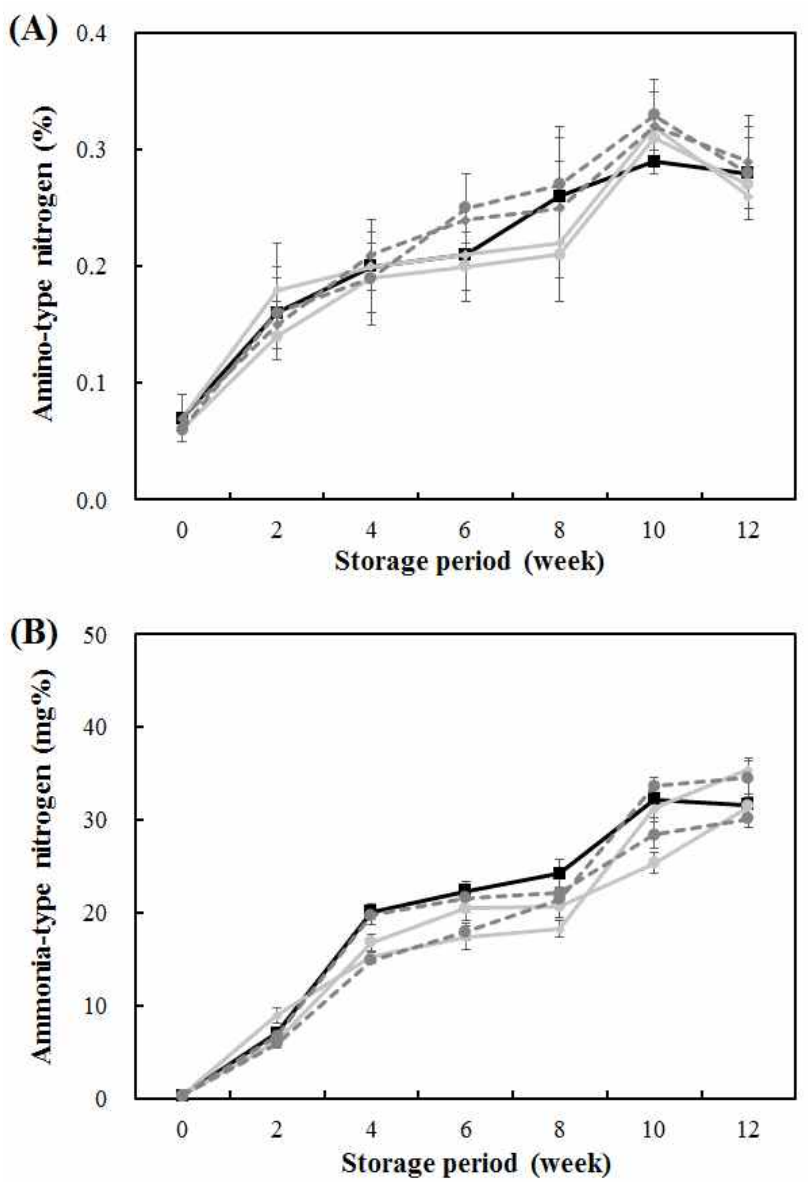

Fig. 4. Changes in amino and ammonia type nitrogen contents of Doenjang during fermentation at $20^{\circ} \mathrm{C}$.

$\rightarrow$ Control $\longrightarrow$ SYM4 $\longrightarrow$ SYM8 $-\rightarrow$ YWM4 - - YWM8 SYM, Shinyulmi sweet potato added Doenjang, YWM, Yeonwhangmi sweet potato added Doenjang. 
natto 된장에 비하여 아미노산성 질소의 함량은 높았다고 보고한 바 있다. 시험구간에는 고구마를 혼합한 된장이 대 조구에 비하여 총질소 함량이 적었음에도 불구하고 아미노 산성 질소 함량에서는 차이가 없었다. 암모니아성 질소는 담금 초 $0.28 \mathrm{mg} \%$ 이었으나 발효가 진행되면서 단백질의 분해로 증가되어 대조구의 10 주를 제외하고는 12 주에 30.12-35.61 mg\%로 증가하였고, 근소하지만 고구마를 혼 합한 된장이 소맥분을 이용한 대조구에 비하여 발효 후기에 암모니아성 질소의 생성이 높아지는 경향이었다. 따라서 개량식 된장의 경우 발효 60-70일 경에 암모니아성 질소는 $44-90 \mathrm{mg} \%$ 로 최고함량을 보였던 Park 등(6)과 발효 90일에 79-107 mg\%로 최고에 달하였던 Kim 등(13)의 보고에 비하 여 암모니아성 질소는 낮은 편이었다. 이러한 결과는 본 실험 된장의 경우 알코올을 $3 \%$ 첨가하여 된장을 담았기 때문에 발효중 품질에 좋지 않은 영향을 주는 암모니아성 질소의 생성이 억제되었던 것으로 판단되었다.

\section{관능검사}

12 주 발효숙성 된 된장의 관능평가 결과는 Table 7 과 같이 맛은 밤고구마를 $8 \%$ 혼합한 된장이 대조구나 호박고 구마 혼합 된장에 비하여 유의적 $(\mathrm{p}<0.05)$ 으로 좋았으며 다 음으로 밤고구마 $4 \%$ 혼합 된장이 좋은 평가를 받았다. 색은 유의성은 없으나 밤고구마 $4 \%, 8 \%$ 혼합 된장이 대조구나 호박고구마 혼합 된장에 비하여 양호하였는데, 이는 Table 5 에서 12 주 숙성 후 밤고구마 혼합구가 $\mathrm{L}$ 과 $\mathrm{a}, \mathrm{b}$ 값이 높았던 결과에 기인한다. 향기는 밤고구마 $8 \%$ 혼합구가 호박고구 마 혼합구에 비하여 유의적으로 좋아 $(\mathrm{p}<0.05)$, 전체적인 기 호도는 밤고구마 $8 \%$ 혼합구가 대조구나 호박고구마 혼합 된장에 비하여 유의적 양호하였다( $\mathrm{p}<0.05)$. 따라서 고구마 를 이용한 된장의 제조는 호박고구마보다는 밤고구마가 유리하여, 소맥분의 일부를 밤고구마로 대체하면 관능적으 로 우수한 것으로 판단되었다.

Table 7. Result of sensory evaluation of Doenjang aged for 12 weeks

\begin{tabular}{ccccc}
\hline Doenjang & Taste & Color & Flavor & $\begin{array}{c}\text { Overall } \\
\text { acceptability }\end{array}$ \\
\hline Control & $4.53 \pm 1.17^{2) \mathrm{b3})}$ & $4.90 \pm 1.40$ & $4.80 \pm 1.22^{\mathrm{ab}}$ & $4.50 \pm 1.23^{\mathrm{b}}$ \\
SYM4 & $5.10 \pm 1.16^{\mathrm{ab}}$ & $5.27 \pm 0.94$ & $4.77 \pm 1.01^{\mathrm{ab}}$ & $5.03 \pm 0.81^{\mathrm{ab}}$ \\
SYM8 & $5.53 \pm 1.07^{\mathrm{a}}$ & $5.20 \pm 1.23$ & $5.27 \pm 1.08^{\mathrm{a}}$ & $5.40 \pm 1.07^{\mathrm{a}}$ \\
YWM4 & $4.73 \pm 1.23^{\mathrm{b}}$ & $4.83 \pm 0.83$ & $4.47 \pm 1.28^{\mathrm{b}}$ & $4.67 \pm 0.92^{\mathrm{b}}$ \\
YWM8 & $4.60 \pm 1.57^{\mathrm{b}}$ & $4.90 \pm 1.37$ & $4.43 \pm 1.38^{\mathrm{b}}$ & $4.70 \pm 1.37^{\mathrm{b}}$ \\
\hline
\end{tabular}

${ }^{1)}$ SYM, Shinyulmi sweet potato added Doenjang, YWM, Yeonwhangmi sweet potato added Doenjang.

${ }^{2)}$ Values are mean \pm SD.

${ }^{3)}$ Means with the same letter in column are not significantly different by Duncan's multiple range test $(\mathrm{p}<0.05)$.

\section{요 약}

된장 담금시 소맥분의 일부를 고구마로 대체하여 고구마 가 된장의 이화학적 품질 특성에 미치는 영향을 비교하였 다. 된장의 효모수는 발효 4 주 이후에 감소하였고, 호기성 세균은 발효 후기에 증가하였다. Amylase 활성은 발효 8 주 이후에 증가하였고, 발효 중에 산성 protease는 감소하였으 나 중성 protease는 높은 활성을 유지하였다. 색도는 발효중 $\mathrm{L}$ 값과 $\mathrm{b}$ 값은 저하하였으나 $\mathrm{a}$ 값은 증가하였다. 된장의 $\mathrm{pH}$ 는 발효 10 주까지 저하하였고 적정산도는 고구마 혼합 구에서 낮았다. 산가는 밤고구마 혼합 된장에서 높았으며, 발효가 진행되면서 된장의 수분활성도와 산화환원전위는 저하되었으나 시험구간의 차이는 없었다. 환원당은 발효 2-6주 이후에 감소하여 고구마 혼합구에서 낮았고, 알코올 은 2주 이후에 서서히 감소하였다. 된장의 아미노산성과 암모니아성 질소는 발효 중에 증가되어 각각 10 주와 12 주 에 최고에 달했다. 12 주 발효된 된장의 기호도는 맛과 향기, 전체적인 기호도에서 밤고구마 $8 \%$ 혼합구가 대조구나 호 박고구마 혼합구에 비하여 유의적으로 양호하였다 $(\mathrm{p}<0.05)$.

\section{References}

1. Lee KI, Moon RJ, Lee SJ, Park KY (2001) The quality assessment of Doenjang added with Japanese apricot, garlic and ginger, and Samjang. Korean J Soc Food Cook Sci, 17, 472-477

2. Rhee CH, Lee JB, Jang SM (2000) Changes of microorganism, enzyme activity and physiological functionality in the traditional Deonjang with various concentrations of Lentinus edodes during fermentation. J Korean Soc Agri Chem Biotechnol, 43, 277-284

3. Jung BM, Roh SB (2004) Physicochemical quality comparison of commercial Doenjang and traditional green tea Doenjang. J Korean Soc Food Sci Nutr, 33, 132-139

4. Ku KH, Choi EJ, Park WS (2009) Quality characteristics of Doenjang added with red pepper (Capsicum annuum L.) seed. J Korean Soc Food Sci Nutr, 38, 1587-1594

5. Kim ZU, Hur BS, Park WP (1989) Utilization of soymilk residue for barley Doenjang. J Korean Agric Chem Soc, 32, 91-97

6. Park SO, Lee TS (1985) Effect of raw materials and volume of Koji on the quality of soy bean paste. J Seoul Woman's University, 14, 437-454

7. Joo HK, Oh KT, Kim DH (1992) Effects of mixture 
of improved Meju, Korean traditional Meju and Natto on soybean paste fermentation. J Korean Agric Chem Soc, 35, 286-293

8. Joo HK, Kim DH, Oh KT (1992) Chemical composition changes in fermented Doenjang depend on Doenjang Koji and its mixture. J Korean Agric Chem Soc, 35, 351-360

9. Kim EY, Rhyu MR (2000) The chemical properties of Doenjang prepared by Monascus koji. Korean J Food Sci Technol, 32, 1114-1121

10. Lee S, Kim DH (2012) Changes in physicochemical properties of low-salt Doenjang during fermentation. Korean J Food Sci Technol, 44, 592-599

11. Jeong MW, Jeong JK, Kim SJ, Park KY (2013) Fermentation characteristics and increased functionality of Doenjang prepared with bamboo salt. J Korean Soc Food Sci Nutr, 42, 1915-1923

12. Park JS, Lee MY, Kim JS, Lee TS (1994) Compositions of nitrogen compound and amino acid in soybean paste (Doenjang) prepared with different microbial sources. Korean J Food Sci Technol, 26, 609-615

13. Kim JH, Yoo JS, Lee CH, Kim SY, Lee SK (2006) Quality properties of soybean pastes made from $M e j u$ with mold producing protease isolated from traditional Meju. J Korean Soc Appl Biol Chem, 49, 7-14

14. Eum BW, Kwak BY, Kim SY, Shon DH, Lee KH (2003) Enhancement of chitooligosaccharides in Doenjang (soybean paste) and Kanjang (soy sauce) using Bacillus subtilis Koji and Rhizopus oryzae Koji. Korean J Food Sci Technol, 35, 291-296

15. Kwon DJ, Kim YJ, Kim HJ, Hong SS, Kim HK (1998) Changes of color in Doenjang by different browning factors. Korean J Food Sci Technol, 30, 1000-1005

16. Kim ND (1996) Study on the browning and it ' $s$ inhibition in soybean paste (Doenjang). Ph D Thesis, Konkuk University, Seoul, Korea, p 1-116

17. Kwak EJ, Lim SI (2003) Effect of addition time of antibrowning agents on browning and fermentation characteristics in Doenjang. J Korean Soc Food Sci Nutr, 32, 495-500

18. Kim JS, Choi SH, Lee SD, Lee GH, Oh MJ (1999) Quality changes of sterilized soybean paste during its storage. J Korean Soc Food Sci Nutr, 28, 1069-1075

19. Han JS (2004) Preparation of mixed beverages for breakfast made primarily with the hydrolysate of sweet potato and its quality characteristics. Korean J Soc Food Cook Sci, 20, 271-278

20. Jeong BC, Ahn YS, Chung MN, Lee JS, Oh YH (2002) Current status and prospect of quality evaluation in sweet potato. Korean J Crop Sci, 47, 124-134

21. Oh HE, Hong JS (2008) Quality characteristics of Sulgidduk added with fresh sweet potato. Korean J Food Cook Sci, 24, 501-510

22. Bae JO, Lee KJ, Park JS, Choi DS (2012) Preperation of sweet potato Doenjang using colored sweet potato. Korean J Food Nutr, 25, 527-537

23. Park SJ, Kim DH (2007) Effect of combined use of various anti-microbial materials on brewing of low salted Kochujang. J Korean Soc Appl Biol Chem, 50, 287-294

24. Fuwa H (1954) A new method for microdetermination of amylase activity by the use of amylose as the substrate. J Biochem, 41, 583-603

25. Anson ML (1938) The estimation of pepsin, trypsin, papain, and cathepsin with hemoglobin. J Gen Physiol, 22, 79-89

26. Official Methods of Miso Analysis (1968) Institute of Miso Technologists, Tokyo, Japan, p 1-34

27. Kim DH, Lee JS (2001) Effect of condiments on the physicochemical characteristics of traditional Kochujang during fermentation. Korean J Food Sci Technol, 33, 353-360

28. James MJ (2000) Modern Food Microbiology. $6^{\text {th }}$ ed, APAC, Las Vegas, NV, USA, p 45-47 